\title{
Pengembangan Video Pembelajaran Materi Kubus dan Balok untuk Meningkatkan Pemahaman Konsep Matematis Peserta Didik
}

\author{
Surur Rofilah ${ }^{1}$, Ayu Tsurayya ${ }^{2}$ \\ 1,2 Pendidikan Matematika, Fakultas Keguruan dan Ilmu Pendidikan, Universitas Muhammadiyah Prof. Dr. Hamka \\ Jl. Tanah Merdeka No 20, Jakarta Timur, Indonesia \\ sururrofilah@gmail.com
}

\begin{abstract}
Students in Indonesia experience difficulties in understanding a concept, applying concepts, and skills in working on problems on cubes and blocks. To make it easier for students to understand a concept, it is necessary to use a learning media. One of them uses learning videos. This study aims to develop learning videos that can improve students' understanding of mathematical concepts and to determine the feasibility of learning videos used in cube and block material. This type of research is development research using a 4-D model. The results of the research are producing cube and block material learning videos to improve students' understanding of mathematical concepts and the results of validating the feasibility of cube and block material learning videos by material experts getting an assessment with a percentage of $88 \%$ in good category, while media experts get an assessment with a percentage of $89 \%$ good category. It can be concluded that the cube and block material learning video is effectively used as a learning medium that is able to improve students' understanding of mathematical concepts because the effectiveness of the cube and block material learning video in small group trials obtains a percentage of $87 \%$ in good category. While in the large group trial, the percentage was $50 \%$ before using the learning video and $78 \%$ after using the learning video.
\end{abstract}

Keywords: Learning Videos, Understanding Mathematical Concepts

\begin{abstract}
Abstrak
Peserta didik di Indonesia mengalami kesulitan dalam memahami suatu konsep, penerapan konsep, dan keterampilan dalam mengerjakan soal pada kubus dan balok. Untuk mempermudah peserta didik dalam memahami suatu konsep, perlu menggunakan suatu media pembelajaran. Salah satunya menggunakan video pembelajaran. Penelitian ini bertujuan untuk mengembangkan video pembelajaran yang dapat meningkatkan pemahaman konsep matematis peserta didik dan untuk mengetahui kelayakan video pembelajaran yang digunakan dalam materi kubus dan balok. Jenis penelitian ini yaitu penelitian pengembangan dengan menggunakan model 4-D. Hasil penelitian yaitu menghasilkan video pembelajaran materi kubus dan balok untuk meningkatkan pemahaman konsep matematis peserta didik dan hasil validasi kelayakan video pembelajaran materi kubus dan balok oleh ahli materi memperoleh penilaian dengan persentase $88 \%$ berkategori baik, sedangkan oleh ahli media memperoleh penilaian dengan persentase sebesar $89 \%$ berkategori baik. Dapat disimpulkan bahwa video pembelajaran materi kubus dan balok efektif digunakan sebagai media pembelajaran yang mampu meningkatkan pemahaman konsep matematis peserta didik karena efektifitas video pembelajaran materi kubus dan balok dalam uji coba kelompok kecil memperoleh persentase sebesar $87 \%$ berkategori baik. Sedangkan dalam uji coba kelompok besar memperoleh persentase $50 \%$ sebelum menggunakan video pembelajaran dan $78 \%$ setelah menggunakan video pembelajaran.
\end{abstract}

Kata kunci: Video Pembelajaran, Pemahaman Konsep Matematis

Copyright (c) 2021 Surur Rofilah, Ayu Tsurayya

$\square$ Corresponding author: Surur Rofilah

Email Address: sururrofilah@gmail.com (Jl. Tanah Merdeka No. 20, Jakarta Timur, Indonesia)

Received 14 July 2021, Accepted 22 July 2021, Published 06 August 2021

\section{PENDAHULUAN}

Salah satu tujuan utama dalam pembelajaran matematika adalah harus memahami suatu konsep. Menurut Nela (dalam Suraji et al., 2018) tujuan dari pembelajaran matematika adalah agar peserta didik memiliki kemampuan diantaranya: (1) memahami konsep matematika, menjelaskan keterkaitan antar konsep dan mengaplikasikannya secara fleksibel, tepat, efesien, dan teliti dalam pemecahan masalah. (2) melakukan manipulasi matematika dalam membuat generalisasi, menjelaskan pendapat dan pernyataan matematika dengan menggunakan penalaran pada pola dan sifat. (3) memecahkan masalah yang 
diantaranya memahami masalah, menyusun model matematika, menyelesaikan model matematika dan menjelaskan hasil. (4) menyampaikan pendapat dengan simbol, tabel, diagram, atau media lain untuk memperjelas masalah. (5) memiliki rasa ingin, ketertarikan, dan minat dalam matematika, serta sikap giat dan percaya diri dalam pemecahan masalah sebagai kegunaan matematika dalam kehidupan.

Namun, masih banyak peserta didik di Indonesia yang lemah dalam memahami konsep matematika. Wahyudin mengatakan bahwa salah satu penyebab peserta didik yang lemah dalam matematika yaitu kurangnya kemampuan untuk memahami konsep-konsep matematika yang berkaitan dengan pokok bahasan yang sedang dipelajari (Rohaeti, 2012).

Mulyanti, Yani, dan Amelia (dalam Maryanih et al., 2018) mengatakan bahwa apabila peserta didik telah mengetahui konsep matematika dengan baik, maka matematika akan mudah dipelajari. Berdasarkan data di lapangan yang disimpulkan oleh (Fahlevi \& Zanthy, 2020) bahwa peserta didik mengalami kesulitan dalam pemahaman konsep, penerapan konsep, dan keterampilan dalam mengerjakan soal pada bangun ruang sisi datar. Kubus dan balok merupakan salah satu bangun ruang sisi datar dan materi pokok matematika yang wajib dipelajari oleh peserta didik sekolah menengah pertama kelas VIII.

Dalam pengajaran pada materi kubus dan balok, perlu menggunakan suatu media pembelajaran karena mempermudah peserta didik dalam memahami konsep, terutama konsep bangun ruang yang didasarkan dengan gambar, sehingga gambar terlihat jelas dan nyata. Hal tersebut bertujuan agar pembelajaran lebih efektif dan efisien, serta lebih bervariasi sehingga adanya daya ketertarikan peserta didik untuk mengikuti proses pembelajaran. Syaiful Bahri (dalam Batubara, 2017) mengungkapkan bahwa adanya media pembelajaran sangat membantu pelajar yang sedang dalam fase operasional nyata dalam memahami materi yang bersifat abstrak atau kurang dipahami jika dijelaskan dengan bahasa verbal. Umumnya, media dalam proses pembelajaran bermanfaat untuk memperlancar interaksi antara peserta didik dengan guru sehingga kegiatan pembelajaran akan menjadi efektif dan efisien, serta dapat membangkitkan minat baru, motivasi dan rangsangan kegiatan pembelajaran, dan berpengaruh pada psikologis peserta didik (Falahudin, 2014).

Media pembelajaran merupakan alat atau bahan atau teknik untuk proses pembelajaran agar merangsang perhatian peserta didik karena lebih bervariasi dan tidak membosankan sehingga dapat menimbulkan motivasi untuk belajar dan meningkatkan pemahaman. Senada dengan apa yang dikatakan oleh (Tafonao, 2018) bahwa media pembelajaran yaitu segala sesuatu berupa alat bantu yang dapat digunakan untuk merangsang pikiran, perasaan, perhatian, dan minat peserta didik untuk belajar serta untuk menyampaikan pesan pengirim kepada penerima. Menurut Sari, Farida, dan Putra (dalam Maharani et al., 2018) dari penggunaan media pembelajaran dalam belajar matematika terdapat dampak positif.

Penerapan teknologi dalam pembelajaran dapat mempermudah peserta didik mempelajari konsep matematika, karena seiring dengan perkembangan ilmu pengetahuan dan teknologi (Khuzaini \& Santosa, 2016). Media video merupakan salah satu media teknologi informasi dan komunikasi yang dapat menjangkau masyarakat luas dan sekaligus paling banyak diketahui (Melinda et al., 2017). Maka dari itu, media video pembelajaran sepadan dengan perkembangan teknologi informasi dan komunikasi dan dapat 
dijangkau dengan jarak jauh, serta dapat meningkatkan pemahaman konsep peserta didik.

Saat ini negara Indonesia sedang menghadapi pandemi Covid-19, di mana mengharuskan untuk menjaga jarak sehingga proses belajar mengajar yang saat ini dilakukan yaitu secara daring. Pada saat proses pembelajaran yang dilakukan dengan komunikasi jarak jauh maka tidak lepas dengan telepon genggam atau laptop dengan koneksi internet yang stabil. Guru memiliki tuntutan untuk kreatif dan inovatif dalam beradaptasi dengan keadaan. Guru harus memerhatikan kondisi peserta didik dalam pelaksanaan pembelajaran daring karena dalam proses pembelajaran daring peserta didik dituntut untuk mempersiapkan perangkat pembelajaran yang sangat memungkinkan terjadi kendala. Oleh karena itu, guru harus mampu menyiapkan alternatif solusi mengenai hal tersebut dengan memberikan perangkat pembelajaran yang mudah digunakan seperti video pembelajaran.

Warsita (dalam Nashrullah et al., 2018) manyatakan video pembelajaran merupakan gabungan dari media visual (gambar) dan media audio (dengar). Materi yang disampaikan lewat video pembelajaran akan mudah dimengerti dengan jelas karena terlihat secara visual dan terdengar secara audio. Jadi video pembelajaran adalah suatu media pembelajaran berupa audio-visual yang berupa gambar bergerak teratur untuk membantu para peserta didik memahami konsep suatu materi.

Penelitian ini menggunakan video pembelajaran dengan menggabungkan audio (suara) dengan visual (gambar) dan menggunakan aplikasi edit video yaitu aplikasi InShot. InShot sebagai salah satu aplikasi editing video yang dapat Menyusun, memotong, menambahkan audio, teks, emoji, efek, dan walaupun aplikasi InShot gratis, aplikasi ini menyediakan pilihan untuk remove watermark (Syukhria, 2021).

Berdasarkan uraian di atas, maka peneliti tertarik untuk melakukan penelitian yang berjudul Pengembangan Video Pembelajaran Materi Kubus dan Balok untuk Meningkatkan Pemahaman Konsep Peserta Didik.

\section{METODE}

Jenis penelitian yang digunakan yaitu $R n D$ (Research and Development) atau penelitian pengembangan. Produk yang sudah dikembangkan dalam penelitian ini yaitu video pembelajaran materi kubus dan balok. Model pengembangan yang digunakan dalam penelitian ini yaitu model 4-D (four-D) untuk menghasilkan produk media video pembelajaran materi kubus dan balok untuk jenjang SMP kelas VIII. Alasan pemilihan model pengembangan 4-D karena tahap-tahap yang terdapat dalam model pengembangan 4-D lebih sederhana dan sistematis sehingga cocok untuk mengembangkan media video pembelajaran sebagai produk dibidang pendidikan.

Populasi target pada penelitian ini adalah semua peserta didik SMP Negeri 5 Karawang Barat Tahun ajaran 2020/2021. Untuk menentukan sampel dalam penelitian ini dilakukan dengan jenis Non-Probability Sampling dan teknik pengambilan sampel menggunakan purposive sampling. Sampel yang dipilih adalah peserta didik kelas VIII berjumlah 10 peserta didik sebagai responden uji coba kelompok kecil dan kelas VIII berjumlah 30 peserta didik sebagai responden uji coba kelompok besar.

Model pengembangan yang digunakan dalam penelitian ini adalah model penelitian pengembangan 
4-D (four-D). Hal ini meliputi 4 tahap yaitu tahap define (pendefinisian), design (perancangan), develop (pengembangan) dan disseminate (penyebaran) yang dapat dijelaskan sebagai berikut:

\section{Tahap Define}

Kebutuhan-kebutuhan di dalam proses pembelajaran serta mengumpulkan informasi-informasi yang berkaitan dengan produk yang akan dikembangkan ditentukan pada tahap pendefinisian. Tahapan ini terdiri dari lima langkah yaitu analisis awal akhir, analisis peserta didik, analisis tugas, analisis konsep dan spesifikasi tujuan pembelajaran. Analisis awal akhir, untuk mengidentifikasi adanya ketakseimbangan antara tujuan kurikulum yang berlaku dengan fakta yang terjadi di lapangan, baik dari segi model, pendekatan, teknik, maupun strategi yang digunakan guru untuk mencapai pembelajaran. Analisis peserta didik, untuk mengamati karakteristik peserta didik yang sesuai dengan desain pengembangan video pembelajaran. Analisis tugas, untuk menganalisis target capaian peserta didik. Analisis konsep, berhubungan dengan materi yang akan disampaikan dalam media video pembelajaran. Spesifikasi tujuan pembelajaran, untuk menentukan perilaku objek penelitian yang diharapkan.

\section{Tahap Design}

Tahap ini terdiri dari empat langkah yaitu penyusunan tes, pemilihan media, pemilihan format, dan rancangan awal. Penyusunan tes, disusun berdasarkan analisis peserta didik dan spesifikasi tujuan pembelajaran yang disesuaikan dengan kemampuan kognitif peserta didik. Pemilihan media, dilakukan untuk mengidentifikasi media pembelajaran yang sesuai dengan analisis tugas, analisis konsep dan karakteristik peserta didik sebagai sasaran serta rencana penyebaran dengan atribut yang bervariasi. Pemilihan format, dilakukan untuk merancang video pembelajaran yang akan dihasilkan peneliti dalam penelitian pengembangan ini. Rancangan awal, yaitu merancang video pembelajaran sehingga menghasilkan prototype $I$.

\section{Tahap Develop}

Setelah prototype I selesai, proses lanjutan dari kegiatan pada tahapan ini yaitu validasi ahli dan uji coba pengembangan. Pada tahap validasi ahli, peneliti meminta validator untuk melakukan penilaian terdapat prototype I. Prototype I akan direvisi berdasarkan masukan dari validator ahli materi dan ahli media sehingga akan dihasilkan prototype II. Uji coba pengembangan terdiri dari uji coba kelompok kecil dan uji coba kelompok besar. Uji coba kelompok kecil merupakan uji coba terbatas yang melibatkan 10 peserta didik kelas VIII sebagai sasaran, uji coba dilakukan untuk mengetahui respons terhadap video pembelajaran yang dikembangkan. Pelaksanaan uji coba kelompok besar akan dilakukan dengan melibatkan 30 peserta didik kelas VIII SMP. Uji coba kelompok besar ini untuk mengetahui efektivitas terhadap video pembelajaran yang dikembangkan, tujuan dari pelaksanaan uji coba kelompok besar adalah untuk mengetahui peningkatan pemahaman konsep matematis peserta didik dinilai dari perbandingan sebelum dan sesudah menggunakan video pembelajaran.

\section{Tahap Disseminate}

Tahap disseminate dilakukan untuk menyebarluaskan produk final video pembelajaran yang dikembangkan dan telah melewati tahap validasi ahli dan uji coba. Produk final berupa video pembelajaran 
materi kubus dan balok. Produk final diharapkan dapat meningkatkan pemahaman konsep matematis dalam pembelajaran matematika.

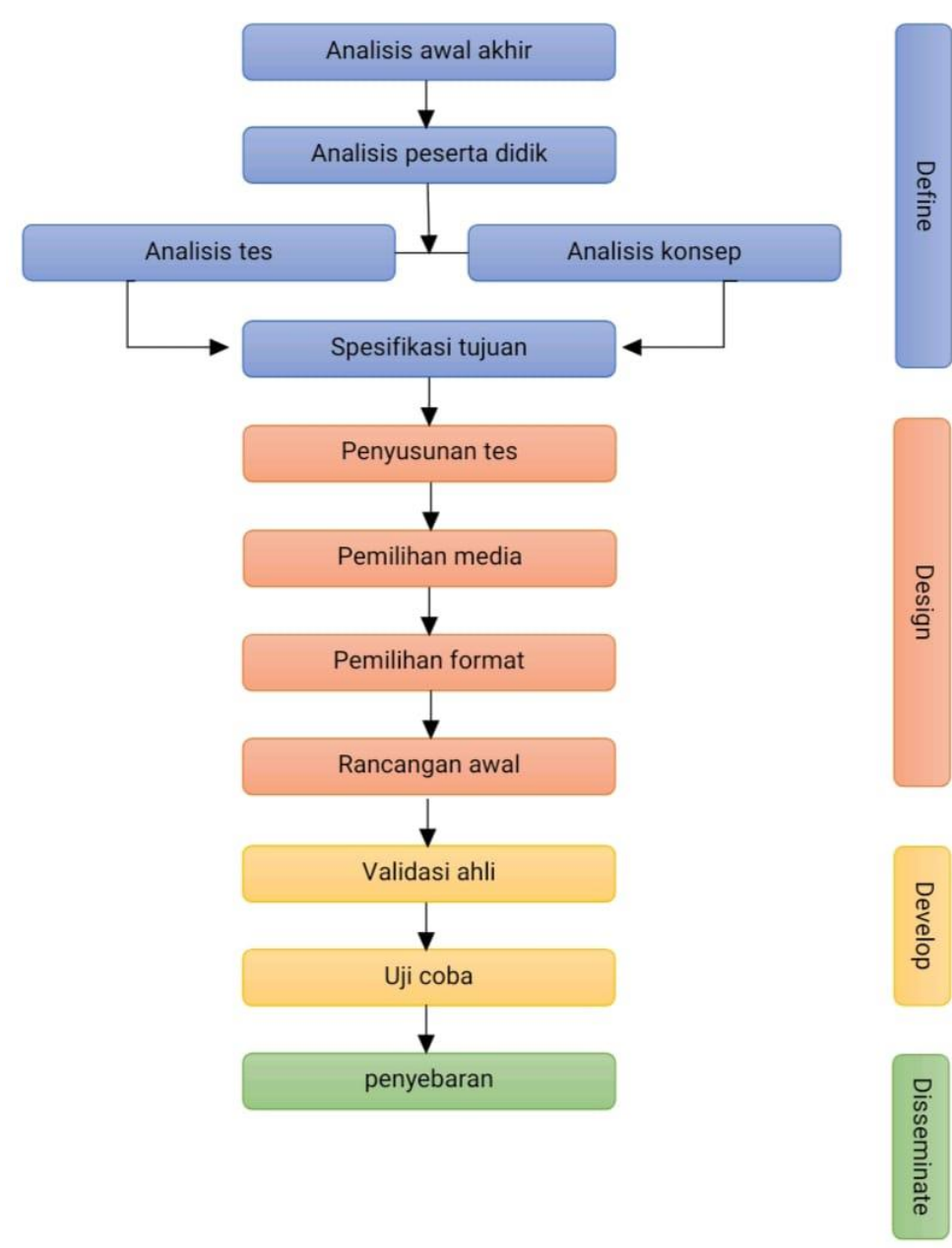

Gambar 1. Tahap-Tahap Model Pengembangan 4-D

Metode Pengujian Instrumen

Instrumen penelitian ini menggunakan skala 4. Data yang diperoleh berupa saran atau masukan untuk perbaikan video pembelajaran serta hasil penilaian dari ahli materi, ahli media, serta respon peserta didik terhadap masing-masing indikator. Skor pada instrument mengikuti ketentuan pada tabel berikut:

Tabel 1. Ketentuan Pemberian Skor

\begin{tabular}{|c|c|}
\hline Kriteria & Skor \\
\hline Sangat Setuju & 4 \\
\hline Setuju & 3 \\
\hline Kurang Setuju & 2 \\
\hline Sangat Kurang Setuju & 1 \\
\hline
\end{tabular}

(Rusli \& Antonius, 2019)

Data yang diperoleh dihitung dengan menggunakan rumus berikut:

$$
\text { Persentase }=\frac{\sum x}{S M I} \times 100 \%
$$

Keterangan: 
Pengembangan Video Pembelajaran Materi Kubus dan Balok untuk Meningkatkan Pemahaman Konsep Matematis Peserta Didik, Surur Rofilah, Ayu Tsurayya

$\sum x \quad$ : jumlah skor

SMI : skor makasimal ideal

Berdasarkan perhitungan di atas maka diperoleh pedoman hasil konversi skor ke nilai pada skala 4 untuk menentukan tingkat kelayakan video pembelajaran yang disajikan pada tabel berikut:

Tabel 2. Pedoman Konversi Skor

\begin{tabular}{|c|c|c|}
\hline Tingkat Pencapaian & Kualifikasi & Keterangan \\
\hline $90 \%-100 \%$ & Sangat Baik & Tidak Perlu Direvisi \\
\hline $75 \%-89 \%$ & Baik & Direvisi Seperlunya \\
\hline $65 \%-74 \%$ & Cukup & Cukup Banyak Revisi \\
\hline $55 \%-64 \%$ & Kurang & Banyak Revisi \\
\hline $0-54 \%$ & Sangat Kurang & Direvisi Total \\
\hline
\end{tabular}

(Tegeh et al., 2014)

Analisis data selain pada pengujian dari para ahli dan respon peserta didik, digunakan pula pada uji efektivitas video pembelajaran kubus dan balok. Data mengenai efektivitas penggunaan video pembelajaran kubus dan balok diperoleh melalui pretest dan posttest yang diberikan kepada peserta didik sebelum dan sesudah menggunakan video pembelajaran kubus dan balok. data tersebut dianalisis menggunakan uji Gain Ternormalisasi. Penggunaan uji Gain Ternormalisasi untuk mengetahui bagaimana peningkatan hasil belajar atau peningkatan pemahaman konsep matematis peserta didik. Besarnya peningkatan sebelum dan sesudah pembelajaran dihitung dengan rumus Gain Ternormalisasi yang dikembangkan oleh Hake (dalam Sundayana, 2018) sebagai berikut:

$$
\text { Gain Ternormalisasi }(g)=\frac{\text { skor post test-skor pre test }}{\text { skor ideal-skor pre test }}
$$

Kategori Gain Ternormalisasi (g) yang telah dimodifikasi oleh (Sundayana, 2018) sebagai berikut:

Tabel 3. Interpretasi Gain Ternormalisasi yang Dimodifikasi

\begin{tabular}{|c|c|}
\hline Nilai Gain Ternormalisasi & Interpretasi \\
\hline$-1,00 \leq g<0,00$ & Terjadi Penurunan \\
\hline$g=0,00$ & Tetap \\
\hline $0,00<g<0,30$ & Rendah \\
\hline $0,30 \leq g<0,70$ & Sedang \\
\hline $0,70 \leq g \leq 1,00$ & Tinggi \\
\hline
\end{tabular}

\section{HASIL DAN DISKUSI}

Penelitian dilaksanakan di SMP Negeri 5 Karawang Barat pada kelas VIII yang sudah melakukan pembelajaran matematika pada materi kubus dan balok. Hasil dari penelitian dan pengembangan ini adalah video pembelajaran kubus dan balok. Model yang digunakan dalam penelitian dan pengembangan ini adalah model pengembangan 4-D, yang terdiri dari empat tahapan diantaranya, define (pendefinisian), design (perancangan), develop (pengembangan), dan disseminate (penyebaran).

\section{Tahap Define}

Hasil wawancara yang peneliti lakukan kepada guru diantaranya, bahan ajar matematika yang 
digunakan peserta didik ada 2, yaitu buku paket matematika yang diberikan dari perpustakaan sekolah dan buku LKS matematika dibeli dari toko buku. Peserta didik masing-masing mempunyai buku paket wajib dan LKS, tetapi ada 2 atau 3 orang yang tidak mempunyai LKS. Selain bahan ajar yang disediakan di sekolah, guru menggunakan bahan ajar lain dalam mengajar yaitu peserta didik dapat mencari materi di internet atau google. Guru tidak melakukan pembelajaran melalui zoom atau google meet. Media pembelajaran yang digunakan dalam pembelajaran matematika saat ini yaitu telegram dan WhatsApp. Respon yang diberikan peserta didik saat melaksanakan pembelajaran dengan bahan ajar yang digunakan baik, jika ada ucapan salam peserta didik menjawab, jika ada pertanyaan dijawab, ada komunikasi antara guru dan peserta didik, begitu juga tugas-tugas ada yang mengerjakan dan tidak mengerjakan. Peserta didik memiliki kemampuan dalam mengulang materi pembelajaran. Saat diberikan tugas 95\% peserta didik selalu mengumpulkan tapat waktu. Peserta didik percaya diri dalam menyelesaikan tugas. Beberapa peserta didik memiliki kesulitan dalam memecahkan masalah pada soal-soal. Dengan menggunakan bahan ajar yang dikembangkan dapat mempermudah guru dalam mengajar karena dapat diakses oleh kebanyakan peserta didik. Dengan menggunakan bahan ajar yang telah dikembangkan sesuai dengan materi (matematika), peserta didik akan lebih aktif dalam pembelajaran.

\section{Tahap Design}

Pada tahap ini menghasilkan prototype I yaitu terdapat video pembelajaran sebanyak dua video. Berikut tampilan dari kedua video yang dirancang oleh peneliti.

Tabel 4. Tampilan Prototype I

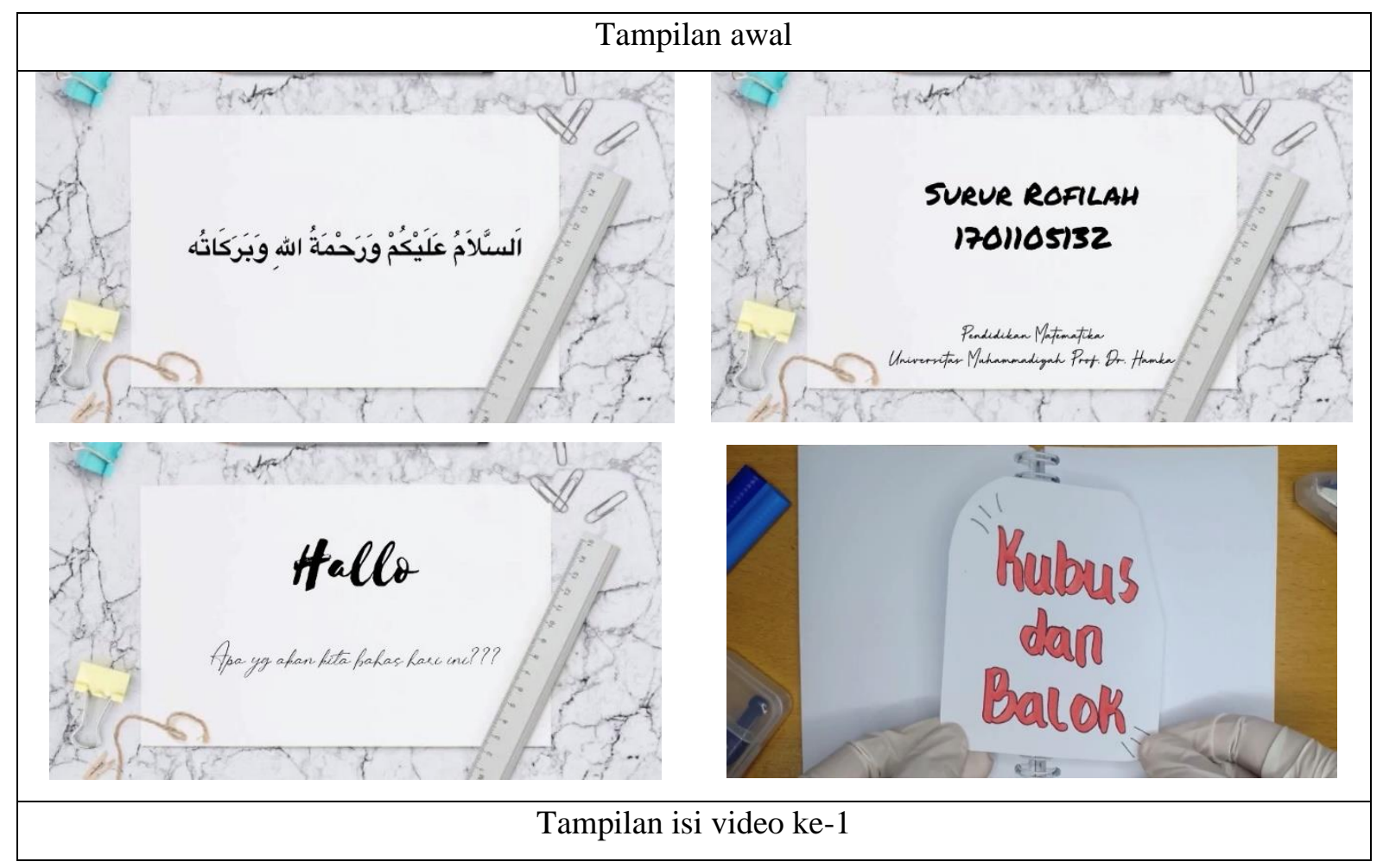



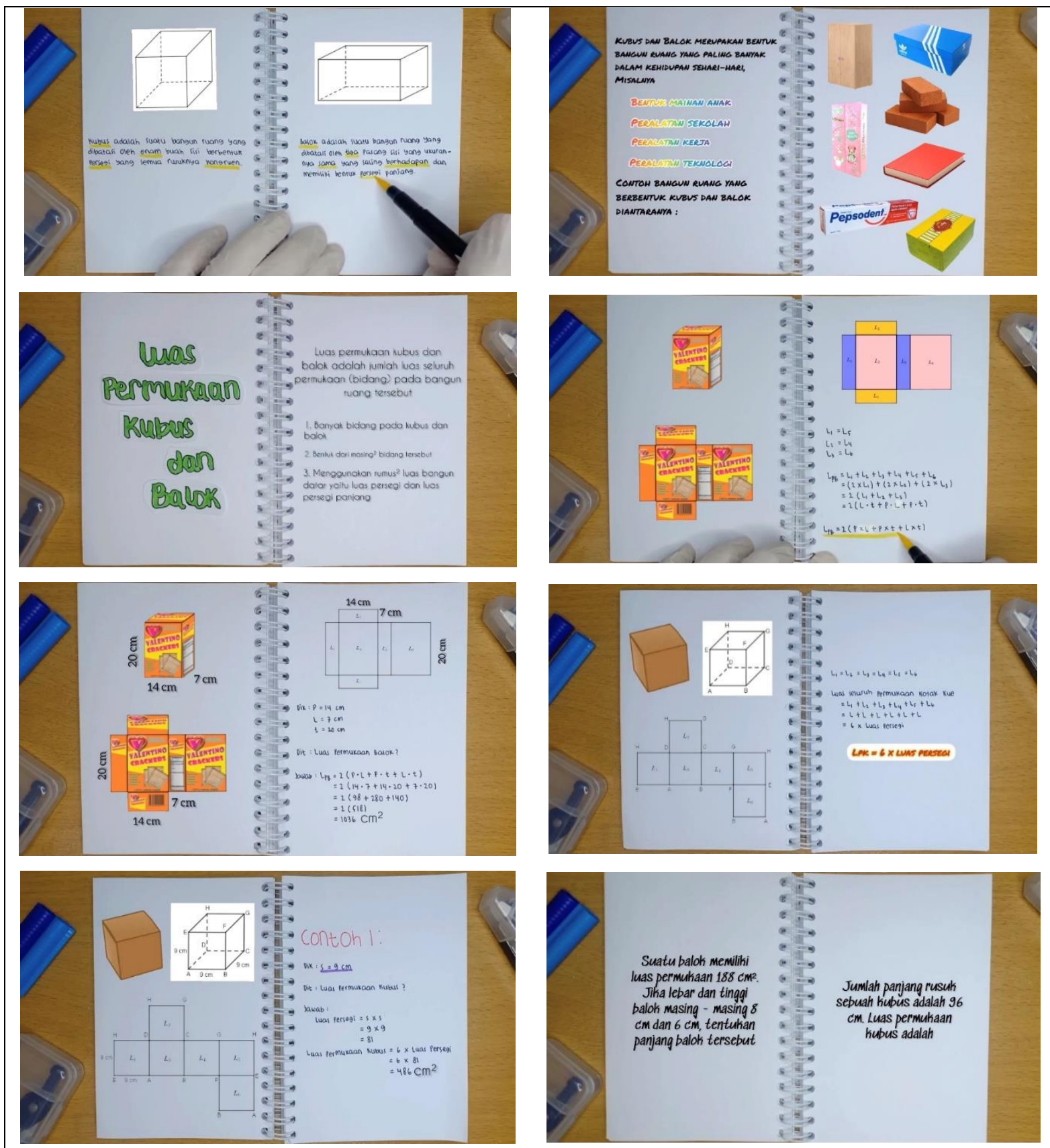

Tampilan isi video ke-2
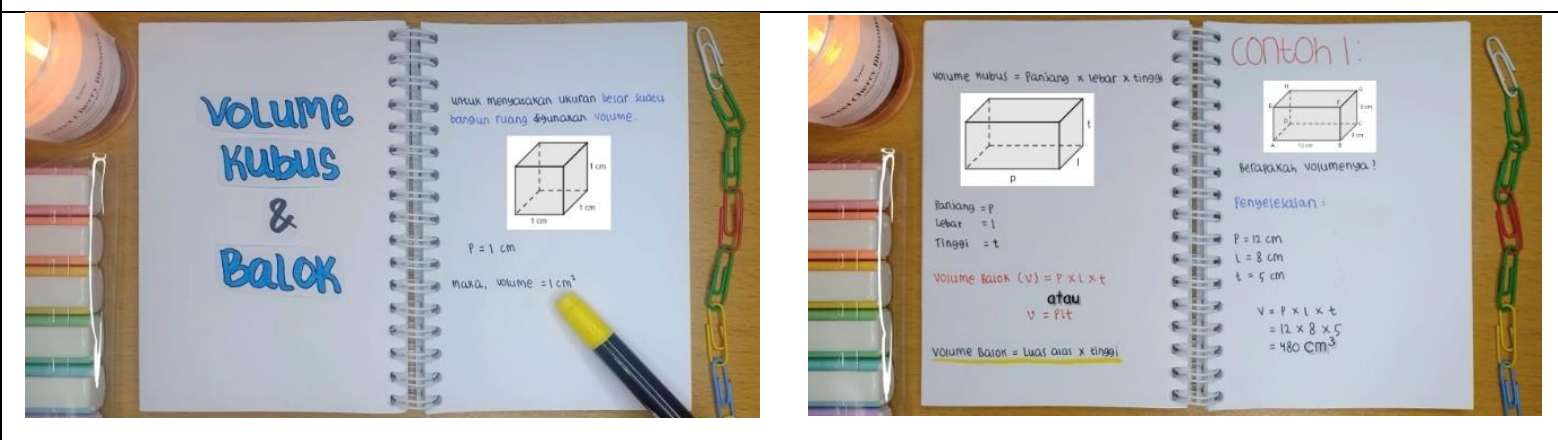


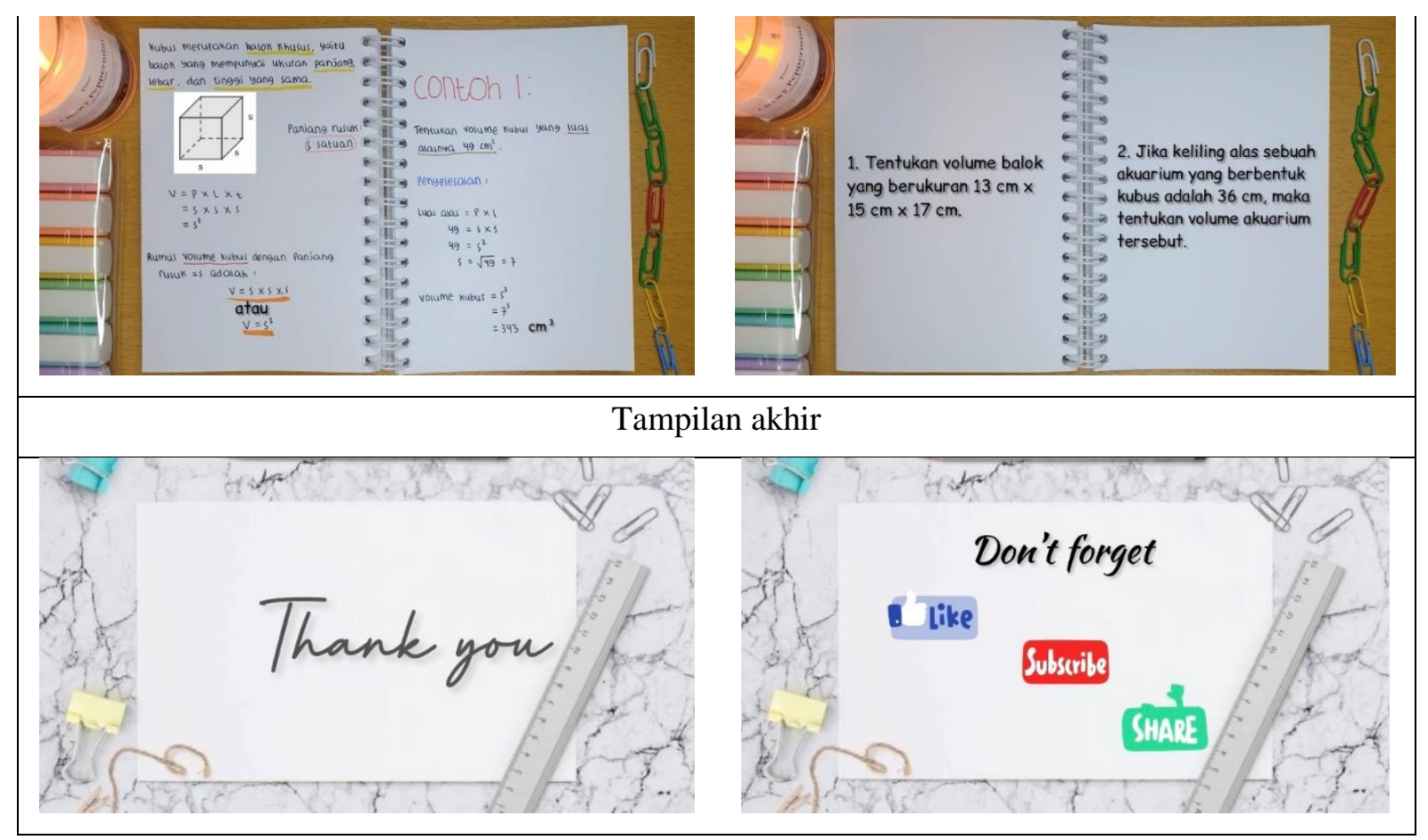

\section{Tahap Develop}

Kelayakan video pembelajaran diukur dari hasil validasi oleh para ahli yang terdiri dari ahli materi dan ahli media. Data yang diperoleh dari validasi kelayakan video pembelajaran oleh ahli materi didapat ratarata persentasi tertinggi diperoleh oleh aspek bahasa dengan persentase $94 \%$ dan berkategori sangat baik. Selain itu, tiga aspek lainnya yaitu aspek kelayakan materi pembelajaran, aspek kemanfaatan materi pembelajaran, dan aspek pemahaman konsep matematis memperoleh persentase 89\%, 85\%, dan $83 \%$ dengan kategori baik. Sedangkan hasil validasi kelayakan video pembelajaran oleh ahli media didapat ratarata persentase tertinggi diperoleh pada aspek kualitas video dan aspek bahasa dengan persentase $90 \%$ dan $100 \%$ berkategori sangat baik. Sedangkan untuk aspek tampilan video memperoleh persentase $82 \%$ dengan kategori baik. Hasil penilaian validasi kelayakan video pembelajaran oleh para ahli baik ahli materi maupun ahli media dapat direkap menjadi rata-rata persentase keseluruhan masing-masing ahli berdasarkan hasil perhitungan. Rekapitulasi hasil validasi oleh para ahli menunjukan bahwa rata-rata persentase ahli materi adalah $88 \%$ dan rata-rata persentase ahli media adalah $89 \%$. Hasil tersebut menunjukan bahwa keduanya berkategori baik dan video pembelajaran layak digunakan.

Selain mendapat hasil penilaian data kuantitatif dari para ahli di atas, berikut disajikan data penilaian kualitatif berupa komentar dan saran yang diberikan oleh para ahli.

Tabel 5. Komentar atau Saran dari Validator Ahli Materi dan Ahli Media

\begin{tabular}{|c|c|}
\hline Validator & Komentar atau Saran \\
\hline Ahli Materi 1 & 1. Instrument dapat digunakan \\
\hline Ahli Materi 2 & 1. Videonya sudah layak untuk pembelajaran \\
\hline Ahli Materi 3 & $\begin{array}{l}\text { 1. Tabel dalam volume balok tidak terlalu jelas dan ngeblur, mungkin bisa } \\
\text { digunakan alternatif lain }\end{array}$ \\
\hline
\end{tabular}




\begin{tabular}{|c|c|}
\hline & 2. Untuk $\mathrm{cm}^{2}$ pengucapan yang benar $\mathrm{cm}$ persegi bukan kuadrat \\
\hline Ahli Media 1 & 1. Sudah cukup baik \\
\hline Ahli Media 2 & $\begin{array}{l}\text { 1. Background kurang menarik } \\
\text { 2. Kualitas video } 1080 \text { tetapi gambar pecah } \\
\text { 3. Saran saya gunakan aplikasi sparkol agar lebih menarik } \\
\text { 4. Bagian opening masih kurang } \\
\text { 5. Bagian closing bisa ditambah ucapan terimakasih atau referensi materi sebagai } \\
\text { credit }\end{array}$ \\
\hline
\end{tabular}

Setelah kelayakan video pembelajaran sudah divalidasi oleh ahli materi dan ahli media kemudian dilakukan perbaikan sesuai dengan saran dari masing-masing validator yaitu prototype II. Berikut tampilan perbaikan dari kedua video yang dirancang oleh peneliti.

Tabel 6. Tampilan Prototype II

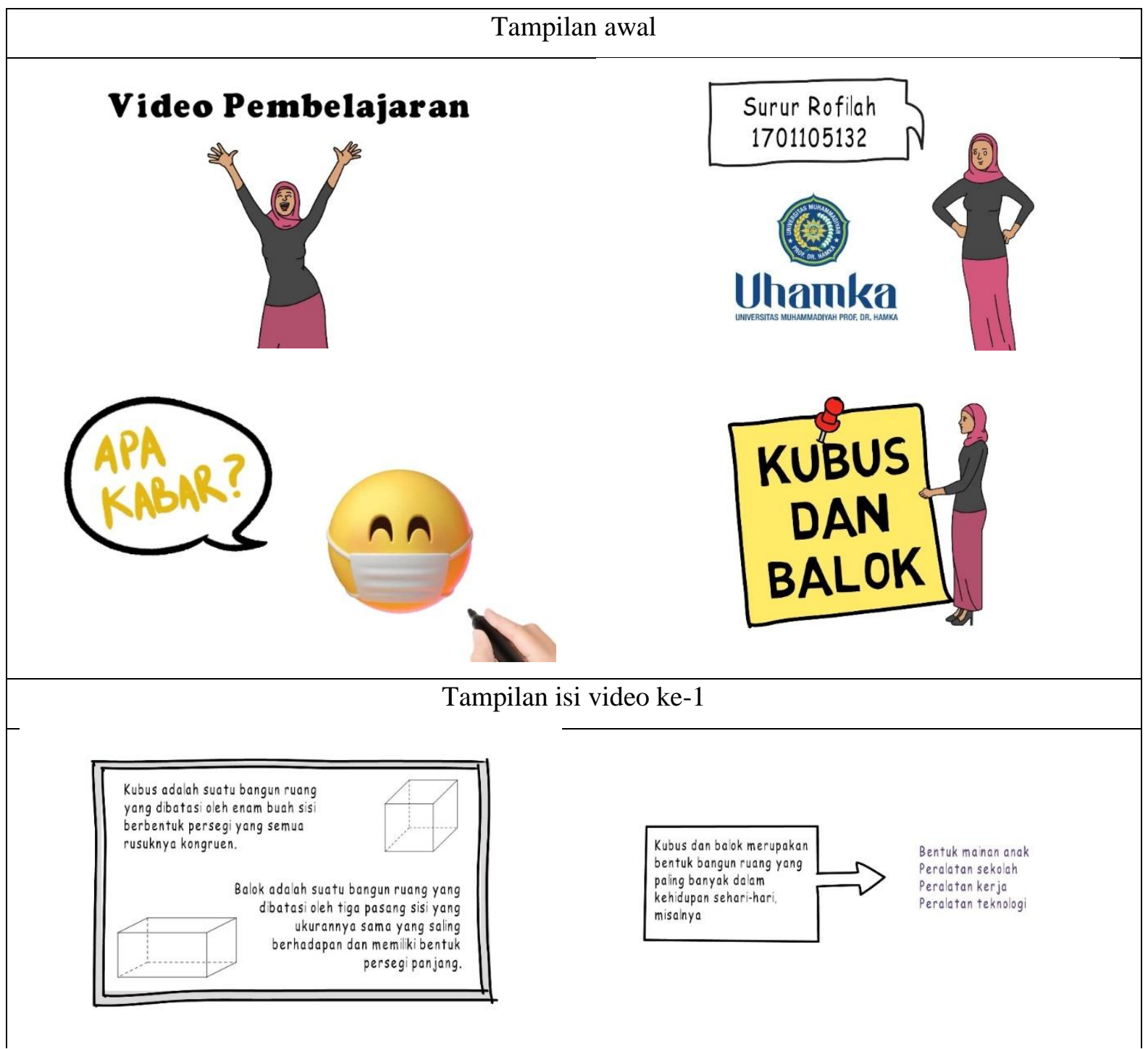


contoh bangun ruang yang berbentuk kubus dan balok diantaranya:
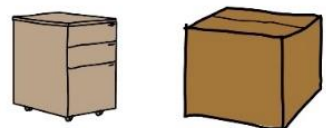

1
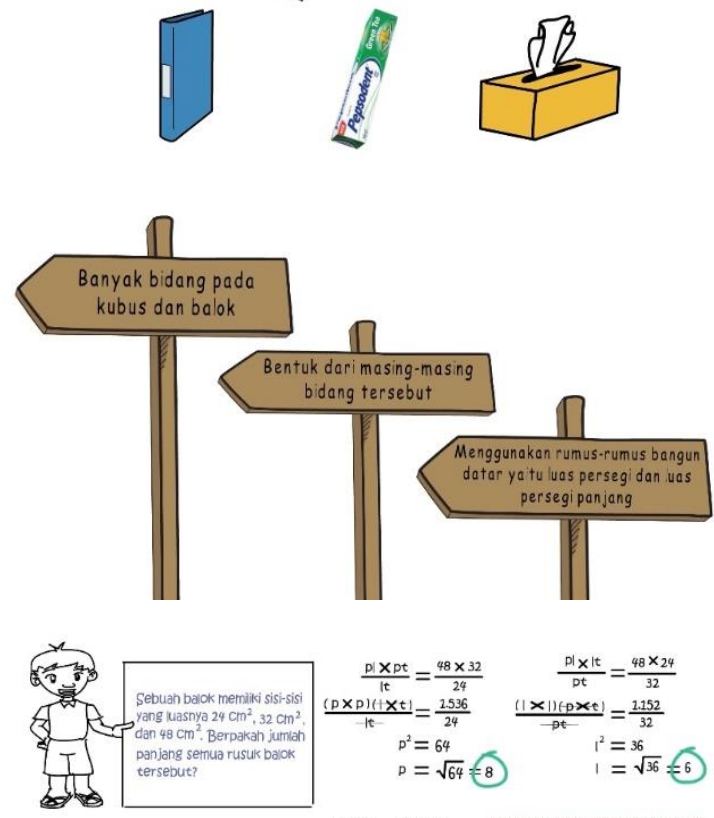

$$
\begin{array}{rlrl}
\frac{p \mid \times p t}{\mid t} & =\frac{48 \times 32}{24} & \frac{p l \times \mid t}{p t} & =\frac{48 \times 24}{32} \\
\frac{(p \times p)(t \times t)}{-t t} & =\frac{2.536}{24} & \frac{(1 \times \mid)(p) \times t)}{p t} & =\frac{1.152}{32} \\
p^{2} & =64 \\
p & =\sqrt{64}=8 & 1 & =36 \\
1^{2} & =\sqrt{36}=-6
\end{array}
$$

$$
\begin{aligned}
\text { dik: misal } p l & =48 \\
\text { pt } & =32 \\
\text { it } & =24
\end{aligned}
$$

dit: juniah panjang semua rusuk balok

$$
\frac{p t \times \mid t}{P !}=\frac{32 \times 24}{48} \quad \text { Sehingsa jumlan panjang rusuk balok }
$$

$$
\begin{aligned}
\frac{D}{(t) t)(p \times)} & =\frac{768}{p !} \\
t^{2} & =16 \\
t & =\sqrt{16}
\end{aligned}
$$

$=4(\mathrm{D}+1+\mathrm{t})$
$=4(8+6+4)$

$=4(28)$

$=$
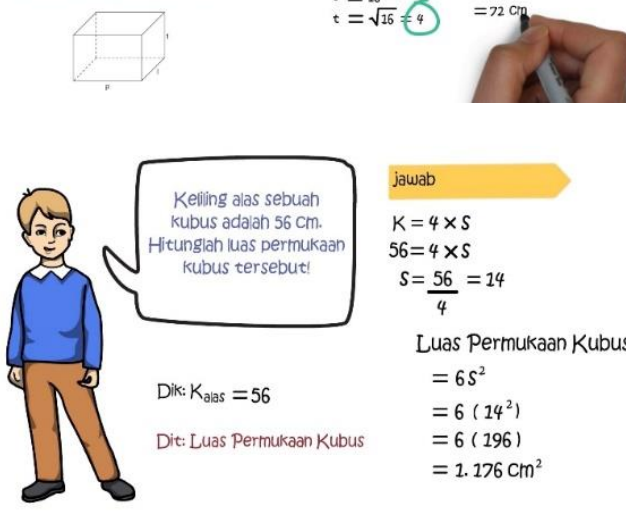

\section{Keliing alas sebuah} kubus adaah $56 \mathrm{~cm}$. kubus tersebut!

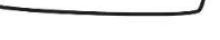

Dik: $K_{\text {alas }}=56$

Dit: Luas Permukaan Kubus

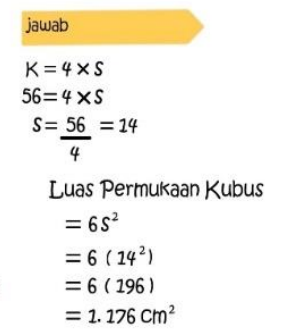

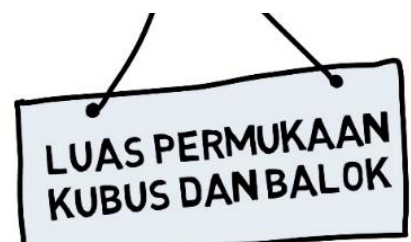

Luas permukaan kubus dan balok adalah jumlah luas seluruh permukaan (bidang) pada bangun ruang tersebut
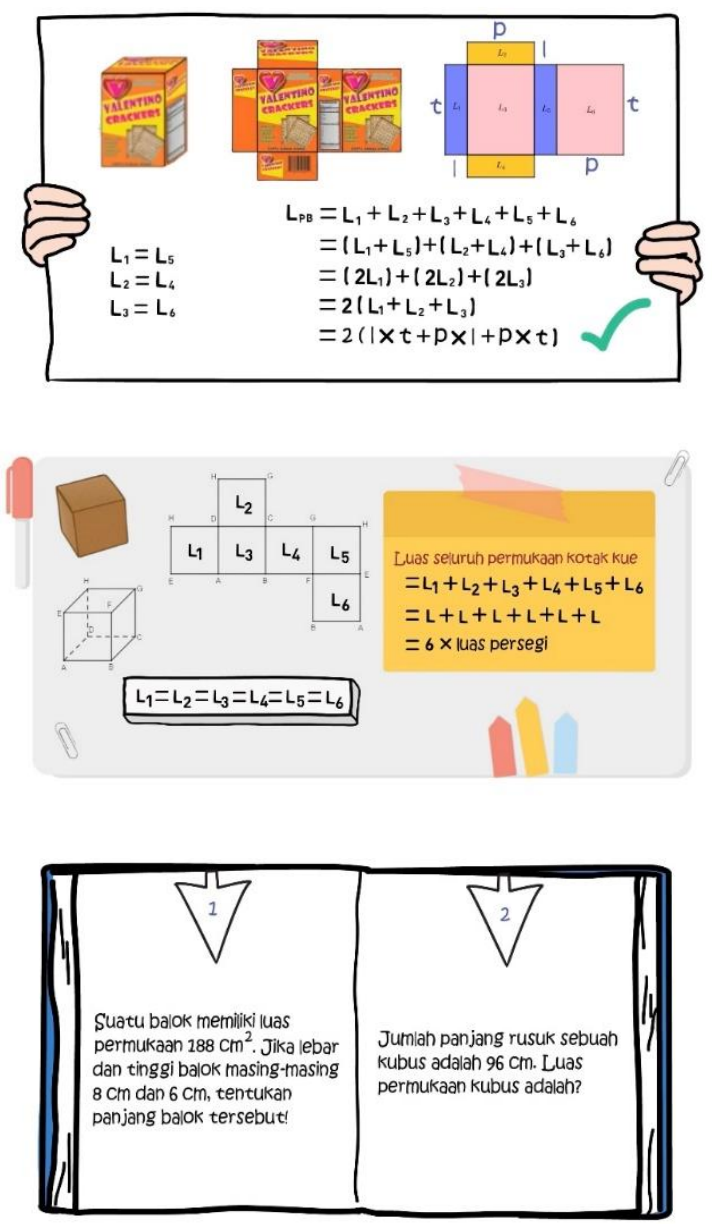

Tampilan isi video ke-2

Untuk menyatakan ukuran besar suatu bangun ruang digunakan volume.

Volume suatu bangun ruang ditentukan dengan membandingkan besar bangun ruang tersebut terhadap satuan pokok volume, misalnya I cm

\section{$\mathrm{P}=1 \mathrm{~cm}$}

Maka, Volume $=1 \mathrm{~cm}^{3}$

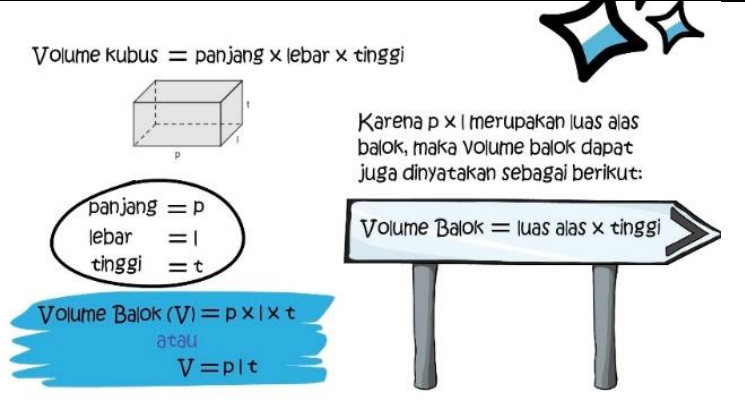




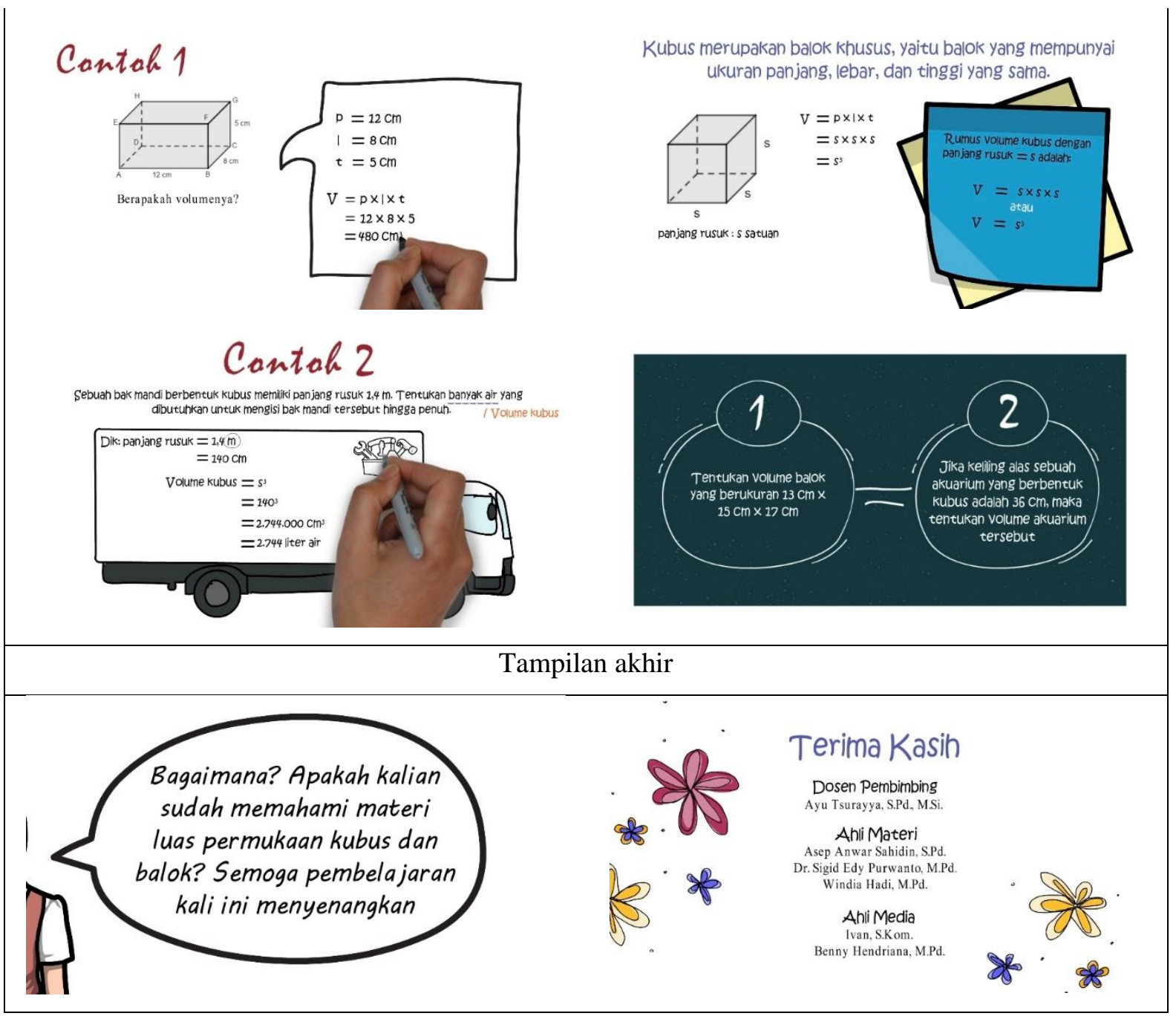

Setelah kalayakan video pembelajaran sudah melewati proses validasi oleh para ahli, langkah selanjutnya yang dilakukan yaitu uji coba pengembangan video pembelajaran dengan tujuan untuk mengetahui tingkat pemahaman konsep matematis peserta didik. Uji coba pengembangan dilakukan dalam dua tahap yaitu uji coba kelompok kecil dan uji coba kelompok besar.

\section{Uji coba kelompok kecil}

Pengujian video pembelajaran dalam kelompok kecil melibatkan 10 peserta didik kelas VIII SMP Negeri 5 Karawang Barat. Data yang diperoleh dari respon peserta didik terhadap video pembelajaran didapat rata-rata persentase keseluruhan $87 \%$ berkategori baik.

\section{Uji coba kelompok besar}

Setelah dilakukan uji coba kelompok kecil, selanjutnya video pembelajaran diujikan pada uji coba kelompok besar dengan banyak responden 30 peserta didik kelas VIII SMP Negeri 5 Karawang Barat. Data yang diperoleh merupakan hasil dari pre test (sebelum menggunakan video pembelajaran) dan hasil dari post test (sesudah menggunakan video pembelajaran). Berikut rekapitulasi hasil perhitungan instrument pemahaman konsep matematis peserta didik sebelum dan sesudah menggunakan video pembelajaran. 
Tabel 7. Hasil Perhitungan Instrument Pemahaman Konsep Matematis Peserta Didik

\begin{tabular}{|c|c|c|c|}
\hline Nilai Gain Ternormalisasi & Interpretasi & Jumlah Peserta Didik & Persentase \\
\hline $0,00<g<0,30$ & Rendah & 1 & $3 \%$ \\
\hline $0,30 \leq g<0,70$ & Sedang & 20 & $67 \%$ \\
\hline $0,70 \leq g \leq 1,00$ & Tinggi & 9 & $30 \%$ \\
\hline
\end{tabular}

Berdasarkan tabel ditunjukan bahwa interpretasi rendah sebanyak 1 peserta didik dengan presentase $3 \%$, interpretasi sedang sebanyak 20 peserta didik dengan presentase $67 \%$, dan interpretasi tinggi sebanyak 9 peserta didik dengan presentase $30 \%$.

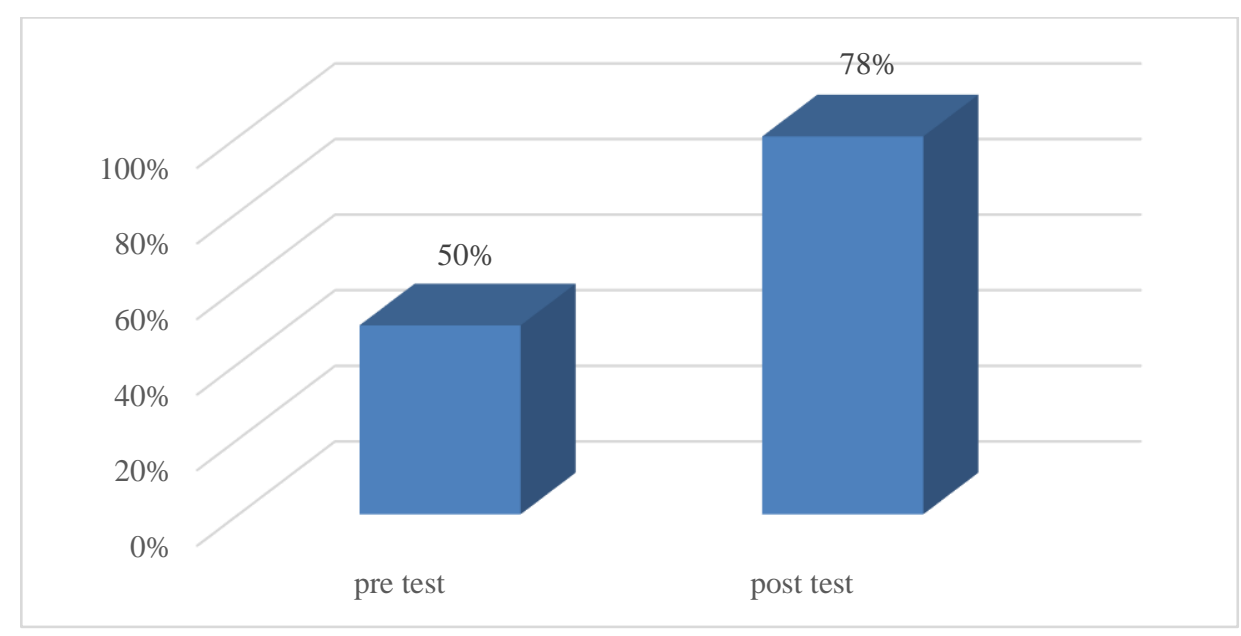

Gambar 2. Hasil Peningkatan Pemahaman Konsep Matematis Peserta Didik

\section{KESIMPULAN}

Berdasarkan penelitian dan pengembangan video pembelajaran materi kubus dan balok untuk meningkatkan pemahaman konsep matematis peserta didik yaitu, pada penelitian ini telah dikembangkan video pembelajaran materi kubus dan balok. Kemudian diperoleh hasil validasi kelayakan video pembelajaran oleh ahli materi memperoleh penilaian dengan persentase sebesar $88 \%$ dan berkategori baik. Sedangkan ahli media memperoleh penilaian dengan persentase sebesar $89 \%$ dan berkategori baik. Efektifitas video pembelajaran materi kubus dan balok dalam uji coba kelompok kecil memperoleh persentase sebesar $87 \%$ dan berkategori baik. Sedangkan dalam uji coba kelompok besar memperoleh persentase $50 \%$ sebelum menggunakan video pembelajaran dan $78 \%$ setelah menggunakan video pembelajaran. Dapat disimpulkan bahwa video pembelajaran materi kubus dan balok mampu meningkatkan pemahaman konsep matematis peserta didik karena adanya peningkatan dilihat dari perbandingan persentase sebelum dan sesudah menggunakan video pembelajaran.

\section{UCAPAN TERIMA KASIH}

Saya ucapkan terimakasih kepada kedua orangtua saya, dosen-dosen program studi Pendidikan Matematika Universitas Muhammadiyah Prof. Dr. Hamka khususnya kepada dosen pembimbing, guru-guru SMP Negeri 5 Karawang Barat, dan seluruh pihak yang telah membantu dalam pelaksaan penelitian ini. 


\section{REFERENSI}

Batubara, H. H. (2017). Pengembangan Media Pembelajaran Matematika berbasis Android untuk Siswa SD/MI. Jurnal Madrasah Ibtidaiyah Muallimuna, 3(1), 12-27.

Fahlevi, M. S., \& Zanthy, L. S. (2020). Analisis Kemampuan Siswa Dalam Menyelesaikan Soal Bangun Ruang Sisi Datar. Jurnal Pembelajaran Matematika Inovatif, 3(4), 313-322. https://doi.org/10.22202/j1.2020.v6i2.3379

Falahudin, I. (2014). Pemanfaatan Media dalam Pembelajaran. Jurnal Lingkar Widyaiswara, 1(4), 104 117.

Khuzaini, N., \& Santosa, R. H. (2016). Pengembangan Multimedia Pembelajaran Trigonometri Menggunakan Adobe Flash Cs3 Untuk Siswa Sma. Jurnal Riset Pendidikan Matematika, 3(1), 8899. https://doi.org/10.21831/jrpm.v3i1.9681

Maharani, M., Supriadi, N., \& Widyastuti, R. (2018). Media Pembelajaran Matematika Berbasis Kartun untuk Menurunkan Kecemasan Siswa. Jurnal Matematika, 1(1), 101-106.

Maryanih, Afrilianto, M., \& Rohaeti, E. E. (2018). Analisis Kesulitan Siswa Smp Dalam Memahami Konsep Kubus Balok. JPMI (Jurnal Pembelajaran Matematika Inovatif), 1(4), 751-758. https://doi.org/10.22460/jpmi.v1i4.p751-758

Melinda, V. A., Degeng, I. N. S., \& Kuswandi, D. (2017). Pengembangan Media Video Pembelajaran IPS berbasis Virtual Field Trip (VFT) pada Kelas V SDNU Kraton-Kencong. JINOTEP, 3(2), 158-164. http://journal2.um.ac.id/index.php/jinotep/article/view/2383

Nashrullah, N., Sulton, \& Soepriyanto, Y. (2018). Pengembangan video pembelajaran adaptasi dan cara berkembang biak makhluk hidup untuk siswa kelas vi sekolah dasar. JKTP, 1(4), 327-332.

Rohaeti, E. E. (2012). Analisis Pembelajaran Konsep Esensial Matematika Sekolah Menengah Melalui Pendekatan Kontekstual Socrates. Infinity Journal, 1(2), 186-191. https://doi.org/10.22460/infinity.v1i2.18

Rusli, M., \& Antonius, L. (2019). Meningkatkan Kognitif Siswa SMAN I Jambi Melalui Modul Berbasis E-Book Kvisoft Flipbook Maker. Jurnal Sistem Komputer Dan Informatika (JSON), 1(1), 59-68. https://doi.org/10.30865/json.v1i1.1397

Sundayana, R. (2018). Statistika Penelitian Pendidikan. ALFABETA.

Suraji, Maimunah, \& Saragih, S. (2018). Analisis Kemampuan Pemahaman Konsep Matematis dan Kemampuan Pemecahan Masalah Matematis Siswa SMP pada Materi Sistem Persamaan Linear Dua Variabel (SPLDV). Suska Journal of Mathematics Education, 4(1), 9-16. https://doi.org/10.24014/sjme.v3i2.3897

Syukhria, R. (2021). Aplikasi Inshot Sebagai Media Pembelajaran Jarak Jauh Pada Pelajaran Bahasa Indonesia. Jurnal Penelitian Pendidikan, 21(1), 34-40. https://doi.org/10.17509/jpp.v21i1.33749

Tafonao, T. (2018). Peranan Media Pembelajaran Dalam Meningkatkan Minat Belajar Mahasiswa. Jurnal Komunikasi Pendidikan, 2(2), 103-114. https://doi.org/10.32585/jkp.v2i2.113

Tegeh, M., Jampel, N., \& Pudjawan, K. (2014). Model Penelitian Pengembangan (Pertama). Graha Ilmu. 